\title{
Factors Affecting Income Diversification of Rural Households in Sodo Zuria Distret, Wolaita Zone, Ethiopia
}

\author{
Samuel Zekarias Adare \\ Department of Economics, Wolaita Sodo University,Wolaita Sodo,Ethiopa \\ Samuel Semma Waje \\ Lecturer, Infolink College, Department of Economics, Wolaita Sodo,Ethiopia
}

\begin{abstract}
In rural areas of developing countries income diversification is influenced by various factors. Thus, the aim of this study was to identify factors affecting income diversification among rural farming households in the Sodo Zuria District,Wolaita zone ,Ethiopia. The study drew a sample of 300 rural farm households through multistage sampling technique from six kebeles of the districts based on agro- ecological category. Data was collected using interview schedule and key informant interviews. Logistic regression model was used to analyze the collected data and the variables. The findings of the study indicate that rural household's income diversification activities which account about $62 \%$ of the households combine agriculture with other activities. Finally, among 15 independent explanatory variables included in logistic regression computation, seven variables such as skill training, education of households, market distance, credit access, extension service, vulnerability to risk/drought, and livestock ownership were very strongly significant. Government and non-governmental organizations and any other concerned stakeholders should emphasis on encouraging agricultural and non- agricultural income diversifying activities.
\end{abstract}

Keywords: Rural household, income diversification, non/off-farming, logistic regression, Wolaita, Ethiopia.

DOI: $10.7176 / \mathrm{JESD} / 12-3-03$

Publication date: February $28^{\text {th }} 2021$

\section{INTRODUCTION}

Now days, a great emphasis has been given to the rural development and poverty reduction in Millennium Development Goal (MDGs) and also a serious attention had been given in Sustainable Development Goal (SDGs) to be implemented globally (United Nations,2012). However, as the indication of many recent literatures , concerning on the issue of rural economic development, still the rural area is saturated with a lot of problems that stagnating its development, and negatively affecting it by putting away from the corner of very fast economic growth that actually observed in urban areas. That is why poverty is pervasive in the rural area (Todaro and Smith, 2009, IFAD, 2011).

Agriculture is the predominant activity for most rural households in Sub Saharan Africa (SSA) including Ethiopia, and it offers a strong option for spurring growth, overcoming poverty and enhancing food security as stressed by the World Bank Report 2008. However, the study conducted by Djurfeldt et al. (2008) indicated that the agricultural sector is characterized by decreasing farm sizes, low levels of output per farm, low productivity and a high degree of subsistence farming. Although enhancing agricultural production is considered to improve the lives of rural people and to ensure food security, agriculture on its own is unable to provide sufficient means of survival and means to escape out of poverty for the majority of poor rural households (Awuor, 2007; World Bank, 2008; Asmah, 2011).

The rural economy of Ethiopia is traditionally viewed as agrarian economy in which farm households are mainly engaged in farming with few off farm and/or nonfarm activities. For instance, only 27 percent of Ethiopian farm households were engaged in nonfarm entrepreneurship (Nagler and Naudé, 2014).

Moreover, majority of the population is dependent on marginal nonfarm income sources such as petty trade (World Bank, 2009). Further, due to the smaller farm size and low return from farming activities, majority of rural households exposed to chronic poverty. For instance, International Food and Agricultural Development (IFAD, 2011) indicated that most of the Ethiopian rural people are poor and access to one hectare or less of land. Hence, if there are no alternative means of livelihoods substituting this situation the newly born generation will face serious challenges than existing. Therefore, these households need to cope with increasing difficulties in agricultural production by diversifying their income into off farm and nonfarm activities.

Agricultural contribution is about 36.2 percent of Ethiopian GDP (CIA world fact book, 2017) and it directly provides employment and livelihood to more than 83 percent of the population, it contributes about 85 percent to its export earnings and supplies around 73 percent of the row material requirement of agro-based domestic industries (Ethiopian Economic outlook, 2016). However, Ethiopian agriculture is characterized by low productivity. Over the last two decades, it has not been able to produce sufficient food to feed the country's rapidly growing population which is currently $103,896,838$, based on the latest United Nations estimates ; that is equivalent 
to 1.39 percent of the total world population (www.worldmeters.info/...population/...., April 30/2017). A close look at the country's declining agricultural outputs and at the same time, ever increasing population growth begs for a search of alternatives (Djurfeldt et al., 2013).

According to Tucker et al. (2010), and Mediksa (2015)[25]; the rural poor often lack access to insurance services, so many individuals prefer strategies to avoid risk. Based on this statement, one strategy for avoiding or minimizing risk is to engage in a wide range of income generating activities so that if one activity fails the individual may fall back on another. As such the rural poor often pursue a diverse range of income generating activities. Reliance on agricultural growth and agricultural strategies alone as the primary vehicle for rural poverty reduction may not be a long term option. Factors such as very small land-holdings, drought, floods, crop loss due to pest and/or disease, poor road status and gaps in market access in rural areas, means that agriculture is already unable to support all of the rural population, leaving many reliant on the Productive Safety Net Program (PSNP) or food aid. It is therefore critical to understand that income diversification enable people to move out of agriculture into new, high earning and more sustainable livelihoods.

According to Yishak (2016), even if there is economic centrality of agriculture in the study area (at sodo zuria woreda,wolaita zone), many households engage and pursue diverse on-farm and off/non-farm livelihood activities to maintain and improve their livelihood/wellbeing. Therefore, comprehending the driving factors of each livelihood strategy is crucial to improve the response mechanisms related to poverty, food security and livelihoods improvement in the study area. However, research work on household income diversification under a condition of resource scarcity in study area is limited. The factors that determine farmers' participation on diversified income generating activities are not well identified. The diverse income sources pursued by rural people in the study area are not assessed in detail. This study therefore aims to assess the existing income sources adopted by the different socioeconomic groups; and identify the determinants that influence farmers' participation in income and diversification.

\subsection{Research Questions}

What are the existing main sources of income diversification in the study area? What are the determinant factors for rural households' income diversification?

\subsection{Objectives of the Study}

The study has general and specific objectives.

1.3.1. General Objective of the Study

To identify the factors that affecting income diversification of rural households in Sodo Zuria District

\subsubsection{Specific Objectives of the Study}

- To identify the existing sources of income diversification that pursued in the rural Households in the study area.

- $\quad$ To determine the major factors that influence income diversification households in the study area.

\section{Data and Methodology}

\subsection{Description of the Study Area}

This study was conducted in Sodo Zuria District, Wolaita Zone of southern Ethiopia. Sodo zuria Woreda is one of rural Woreda administration in Wolaita zone (Southern Nations Nationalities Peoples' Region). The Woreda is located at a distance of $390 \mathrm{~km}$ (to the south) from Addis Ababa.

The Woreda has 30 rural administrative Kebeles. The total land coverage of the woreda was $404.35 \mathrm{~km}^{2}$, and the population density was 471.4 population $/ \mathrm{km}^{2}$. And the population figure of the woreda was male 93,726 , female 96,880 total 190,606 (FDRE, CSA annual statistical abstract, 2013). According to (WLUM ,2002), of which $12269 \mathrm{Ha}(35.75 \%)$ is allocated for crop production, $9067 \mathrm{Ha}(19 \%)$ for fallow land while $12019 \mathrm{Ha}(30.61 \%)$ for grazing land and $7450 \mathrm{Ha}(15.02 \%)$ for forest land.

The agro-ecology of the Woreda is dominated by midland that covers about $87 \%$ of the total area, and the remaining $13 \%$ is highland with rugged mountains and slopes (WFEDO, 2012). Damota Mountain is the highest peak (over 2800 m.a.s.l) in the Woreda and is considered as the main water source to the surrounding communities. All the highland Kebeles are located around the mountain. The altitude of the Woreda falls in the range of 1500 to3200 m.a.s.l. The average annual rainfall of the Woreda is $1200 \mathrm{~mm}$ per annum, while the daily temperature varies from $15^{\circ} \mathrm{C}$ to $30^{\circ} \mathrm{C}$.

\subsection{Target population}

The study area consists of the total population of 44,162 households in the district (BOFEDO, 2017). From which 10,100 households were diversifying their income and the remaining were not. The totals of 1360 households were selected from six study kebelles (villages). The lists of all Households who are participating in diversifying their income and not participating were registered by Sodo Zuria district agricultural development office. 


\subsection{Sampling Technique}

The researcher used a multi-staged sampling procedure. The first stage, the farmers were grouped according to their income diversification by on- farm and off- farm activities. In stage two, a proportionate sampling procedure was used to determine the number of Households to be selected from each of the group based on the sample size. Finally, in stage three, the smallholder households were randomly selected with the use of the balloting system to make up the determined proportion of each category.

Table 1: Sample size determination of income diversification on On-farm and off-farm activities of the study area

\begin{tabular}{llllrrr}
\hline Villages & On - Farm Activity & \multicolumn{2}{l}{ Off-farm activity } & Total households(N) & Sample size(n) \\
\hline & Male & Female & Male & Female & & \\
Buge wanche & 46 & 62 & 72 & 96 & 276 & $\mathbf{6 2}$ \\
Waraza Gerera & 40 & 56 & 80 & 86 & 262 & $\mathbf{6 0}$ \\
Kokate & 56 & 72 & 86 & 100 & 314 & $\mathbf{8 0}$ \\
Waja Kero & 54 & 66 & 60 & 80 & 260 & $\mathbf{5 6}$ \\
H/Larena & 60 & 30 & 20 & 26 & 136 & $\mathbf{2 4}$ \\
Tome Gerera & 44 & 24 & 26 & 18 & 112 & $\mathbf{1 8}$ \\
Total & $\mathbf{3 0 0}$ & $\mathbf{3 1 0}$ & $\mathbf{3 4 4}$ & $\mathbf{4 0 6}$ & $\mathbf{1 3 6 0}$ & $\mathbf{3 0 0}$ \\
\hline
\end{tabular}

Source: Own computation, 2020

\subsubsection{Sample size}

To achieve the objectives of the study 6(six) Kebeles were purposely chosen from the study districts. According to Cochran (1963:75) developed the equation to yield a representative sample for proportions of large sample. Since the numbers of smallholder farmers in the districts are more than 10,000 in the six kebeles, we can use the sample size formula (Cochran 1963:75)

$$
\mathbf{n}_{\mathbf{o}}=\frac{\mathbf{z}^{2} \mathbf{p q}}{\mathbf{e}^{2}}
$$

Which is valid where $\mathbf{n}_{0}$ is the sample size, $\mathbf{Z}^{2}$ is the abscissa of the normal curve with $95 \%$ confidence level and $5 \%$ precision ' $\mathrm{e}$ ' is the desired level of precision, $\mathrm{p}$ is the estimated proportion of an attribute by assuming $\mathrm{p}=0.5$ (maximum variability) that is present in the population, and $\mathrm{q}$ is $1-\mathrm{p}$. The value for $\mathrm{Z}$ is 1.96 which is found in statistical tables which contain the area under the normal curve. By using the above formula, we have;

$$
n_{o}=\frac{Z^{2} p q}{e^{2}}=\frac{(1.96)^{2} * 0.5 * 0.5}{(0.05)^{2}}=\frac{(3.8416) * 0.25}{0.0025}=384
$$

Using infinite population sample size determination formula the total numbers of samples included in the study were $=384$. Since the study targeted six Kebeles smallholders which are registered in district office were less than 10,000 and the study used finite population sample size determination formula (Cochran 1963:75), we have:

$$
\text { no }=\frac{\frac{\text { no }}{1+(\text { no }-1)}}{\mathrm{N}}, \mathrm{n}=\frac{\frac{384}{1+(384-1)}}{1360}=\frac{\frac{384}{1+383}}{1360},=299.76 \approx 300
$$

\subsection{Data types, Sources and collections}

The data collection method relied on primary data which has been collected mainly, interviews and open and closed ended questionnaires. Secondary data are: manuals, reports, proclamations, profiles, and statically data and other national and international reviews. Structured questionnaires were used to collect data on the socio-economic characteristics we considered could affect households' decisions in income diversification. Factors captured by the questionnaire included age sex, marital status, education, family size, farm size, Annual income, Tropical livestock holding size (TLU), extension services, technology utilization, credit utilization, skill training, remittance/transfer, market distance, irrigation utilization, vulnerability to drought/risk; and the error terms (Ui).

\subsection{Methods of Data Analysis}

Two types of data analysis, namely descriptive statistics and econometric models were used to analyze the data collected from sample households. According to descriptive statistical methods, quantitative categorical types of data was analyzed by using percentage, frequency. While quantitative continuous types of variables were been analyzed by using, minimum, maximum, mean and standard deviation. After computing the descriptive statistics, binary logistic regression ( Green,2000) was used to identify factors affecting households' participation in income generation and diversification where the dependent variable was found to be dichotomous (for example, 1 if household participate in income diversification and 0 otherwise. STATA 14 was used for the econometric analysis. 


\section{Empirical Estimation of the Method}

\subsection{Logistic Regression Model}

The logistic model was applied in this study to assist in estimating the probability of farmers' participation in income diversification activities that can take one of the two values, participated or not participated. According to Gujarati [Gujarati, 1995), the functional form of the logit model is presented as follows:

$$
\begin{array}{r}
P i=E(Y i / X i)=1 / 1+e-(\beta 0+\beta 1 x i) \\
P i=E(Y i / x i)=1 / 1+e-z i \ldots \ldots
\end{array}
$$

Where $\mathrm{Pi}$ is a probability that a $i^{\text {th }}$ household participated in income diversification and ranges from 0 to $1 ; \mathrm{Zi}$ is a functional form of $\mathrm{m}$ explanatory variables $(\mathrm{X})$ which is expressed as:

$$
Z i=\beta 0+\sum m i=1 \beta i, \quad, 1,2,3 . m \ldots \ldots \text { (3) }
$$

Where; $\beta 0$ is the intercept and $\beta \mathrm{i}$ are the slope parameters in the model. The slope tells how the log-odds in favor of a given household participating in income diversification change as independent variables change. If $\mathrm{Pi}$ is the probability of a household being in income diversification, then 1-Pi indicates the probability that a given household did not participate in income diversification, which can be given as:

$$
1-P i=1 / 1+e z i
$$

Dividing equation (2) by equation (4) and simplifying gives

$$
e Z i=p i / 1-p i=1+e Z i / 1+e-Z i
$$

Equation (9) indicates the odds ratio in favor/in terms of a given household participating in income diversification. It is the ratio of the probability that a household will participate in income diversification to the probability she/ he will not participate. Lastly, the logit model is obtained by taking the natural logarithm of equation (5) as follows:

$$
L i=\ln (p i / 1-p i)=\beta 0+\beta 1 x i
$$

Where; $\mathrm{Pi}=$ the probability that $\mathrm{Y}=1$ (that a given household is participating in income diversification); 1 $\mathrm{Pi}=$ the probability that $\mathrm{Y}=0$ (that a given household does not participate in income diversification); $\mathrm{L}=$ the natural $\log$ of the odds ratio or logit;

$\beta \mathrm{i}=$ the slope, measures the change in $\mathrm{L}$ (logit) for a unit change in explanatory variables $(\mathrm{X}) ; \beta 0=$ the intercept. It is the value of the log odd ratio; $\mathrm{pi} /(1+\mathrm{pi})$ when $\mathrm{X}$ or explanatory variable is zero. Thus, if the stochastic disturbance term $(\mathrm{U} \mathrm{i})$ is taken into consideration the logit model becomes:

$$
L i=\beta 0+\beta 1 x i+u i
$$

\subsection{Hypotheses}

In this research work, the hypothesized explanatory variables that results the new findings (the output )were assumed to be listed as below. The dependent (response) variable is income diversification $=Y$, which is the probability of rural households engagement in income generation and diversification activities). Therefore, in the below the hypothesized factors that affect income generation and diversification of rural households were listed. Hence, the explanatory or independent variables were: sex of household head $\left(\mathrm{X}_{1}\right)$, age of household head $\left(\mathrm{X}_{2}\right)$, family size $\left(\mathrm{X}_{3}\right)$, land holding size $\left(\mathrm{X}_{4}\right)$, education $\left(\mathrm{X}_{5}\right)$, Tropical livestock holding size $(\mathrm{TLU})\left(\mathrm{X}_{6}\right)$, extension services $\left(\mathrm{X}_{7}\right)$, technology utilization $\left(\mathrm{X}_{8}\right)$, credit utilization $\left(\mathrm{X}_{9}\right)$, skill training $\left(\mathrm{X}_{10}\right)$, remittance/transfer $\left(\mathrm{X}_{11}\right)$, market distance $\left(\mathrm{X}_{12}\right)$, irrigation utilization $\left(\mathrm{X}_{13}\right)$, vulnerability to drought/risk $\left(\mathrm{X}_{14}\right)$; and the error terms $(\mathrm{Ui})$.

$$
\boldsymbol{Y}=\boldsymbol{\beta} \mathbf{0}+\boldsymbol{\beta} \mathbf{1 X} \boldsymbol{i}+\ldots+\boldsymbol{U} \boldsymbol{i}
$$

For analyzing purpose, the logistic regression was used. The variables are

$\mathrm{Y}=$ dependent variable, $\mathrm{X}$ 's= Independent variables, $\mathrm{Bi}=$ the coefficients of determination (estimators) and $\mathrm{Ui}=$ error term .

\subsection{Operational Definition of Variables and Hypothesized Relationships \\ 3.3.1 Dependent Variable}

It is dichotomy variable which represents the household income generation and diversifications strategies. It indicates whether a particular household is engaged in farm alone income generating activities or nonfarm /off farm income generating activities or diversification (farm+ off- farm) income generating activities depending on their engagement in income sources.

\subsubsection{Independent Variables}

The independent variables for the study were identified and listed based on previous theoretical and empirical works. The following explanatory variables were hypothesized to determine factors which are influence income diversification in the study area were sex, age, education, family size, remittances, farm size, frequency of extension contacts, utilization of irrigation, access to skill training, access to credit, vulnerability, distance to market, safety net aid, local leaders, total annual income were the factors. 
Table 2: Definition and units of measurements of explanatory variables of income diversification.

\begin{tabular}{|c|c|c|}
\hline Variables & Description and measurement & $\begin{array}{l}\text { Expected } \\
\text { sign }\end{array}$ \\
\hline $\begin{array}{l}\text { Dependent variables } \\
\text { Engagement in income } \\
\text { diversification } \\
\text { Independent variables }\end{array}$ & $\begin{array}{l}\text { Dummy: } 1 \text { if the household diversifies income, } 0 \text { otherwise Whether } \\
\text { a household head has access to credit or not }\end{array}$ & \\
\hline Sex & $\begin{array}{l}\text { It is a dummy variable taking value } 1 \text { if the household head is male, } \\
0 \text { otherwise }\end{array}$ & + \\
\hline Age & Age of household head (years). & - \\
\hline Educ & $\begin{array}{l}\text { Formal education of household head (grades or number of years in } \\
\text { school). It takes } 0=\text { illiterate, } 1=\text { primary } 2=\text { secondary and } 3=\text { diploma } \\
\text { /degree }\end{array}$ & + \\
\hline Famlsize & Family size of household in number & + \\
\hline Landsize & Total landholding size of household (hectare). & - \\
\hline Remit & $\begin{array}{l}\text { It takes value } 1 \text {, if a household receive remittance money, } 0 \text { if not } \\
\text { involving in it. }\end{array}$ & - \\
\hline TLU . & Total livestock owned by the farm household (TLU) & + \\
\hline Tecno & $\begin{array}{l}\text { It is a dummy variable takes } 1 \text { if a household use improved } \\
\text { technology, } 0 \text { otherwise. }\end{array}$ & + \\
\hline Irrig & Farmer using irrigation, dummy variable ( $=1$, if yes; $=0$, otherwise). & + \\
\hline Skilltra & $\begin{array}{l}\text { Farmer attended skill training, dummy variable }(=1 \text {, if yes; }=0 \text {, } \\
\text { otherwise }) \text {. }\end{array}$ & + \\
\hline Exsvs & Farmers get extension service $(=1$, if yes; $=0$, otherwise $)$ & + \\
\hline Creditace & If households accessed to credit 1 , and 0 otherwise & + \\
\hline Mrktdist & $\begin{array}{l}\text { Distance of the respondents' house from input and output market } \\
(\mathrm{km}) \text {. }\end{array}$ & \\
\hline Vulnerably & $\begin{array}{l}\text { Households vulnerability to drought or risks, dummy variable }(=1 \text {, if } \\
\text { yes; }=0 \text {, otherwise }\end{array}$ & - \\
\hline Localleader & $\begin{array}{l}\text { Households participation in local social organization leadership, } \\
\text { dummy variable takes value of } 1 \text { if a household participated, } 0 \\
\text { otherwise }\end{array}$ & - \\
\hline Safetynetaid & $\begin{array}{l}\text { It takes value } 1 \text {, if a household is beneficiary of safety net program, } \\
0 \text { if not involving in it. }\end{array}$ & + \\
\hline INCOM & Total annual cash income of households (Birr) & + \\
\hline
\end{tabular}

Source: Own computation: 2020

\section{RESULT AND DISCUSSION}

4.1. Descriptive Statistics of the main income diversification activities and annual income of Households As indicated in the below table 3 the main income diversification in the study area are on farm and off- farm activities. The on-farm activities such as crop production (24\%), livestock production (18\%), agricultural wage employment (3.3.\%) and the off-farm income diversification activities such as Petty trade(28.67\%),service providing $(8.67 \%)$ rural craft(3.33\%),wage - employment $(4 \%)$ are the major income diversification means for rural households(Table 3 ) 
Table 3. Main income diversification and amount of annual income in ETB

\begin{tabular}{|c|c|c|c|c|}
\hline Id.No & Source of income & $\begin{array}{c}\text { Number of } \\
\text { participants in income } \\
\text { diversification }\end{array}$ & $\begin{array}{c}\text { Percentage of each } \\
\text { income generating } \\
\text { activities }\end{array}$ & $\begin{array}{c}\text { Annual Income of each } \\
\text { HHs in ETB }\end{array}$ \\
\hline \multirow[t]{5}{*}{1} & On farm activities & & & \\
\hline & Crop production & 72 & 24 & 442835.176 \\
\hline & Livestock production & 54 & 18 & 475396.586 \\
\hline & $\begin{array}{l}\begin{array}{c}\text { Agri. } \\
\text { employment }\end{array} \\
\text { Wage }\end{array}$ & 10 & 3.33 & 12094.238 \\
\hline & Sub Total & 136 & & $930,326.00$ \\
\hline \multirow[t]{8}{*}{2} & Off-farm activities & & & \\
\hline & Petty treading & 86 & 28.67 & 232790.592 \\
\hline & Service providing & 26 & 8.67 & 31317.12 \\
\hline & Rural crafts & 10 & 3.33 & 18442.304 \\
\hline & Wage employment & 12 & 4 & 23661.824 \\
\hline & Remittance & 10 & 3.33 & 13918.72 \\
\hline & Safety net aid & 20 & 6.67 & 27837.44 \\
\hline & Sub Total & 164 & & 347968 \\
\hline
\end{tabular}

Source: field survey, 2020

The annual income means of households also generating from those on and off- farm activities. From the above table, the dominant income sector (source) on- farm activities which accounts the annual income of 930,326.00 ETB and off - farm accounts 347,968.00 ETB. (Table 3)

Table 4: Summary of continuous Variables on income diversification of rural house holds

\begin{tabular}{llllll}
\hline Variables & $\mathbf{N}=\mathbf{3 0 0}$ & Minimum & Maximum & Mean & Std. Deviation \\
\hline Age & 300 & 25 & 70 & 42.84 & $\mathbf{8 . 9 1 2 1 3}$ \\
Family size & 300 & 1 & 14 & 6.08 & $\mathbf{2 . 1 9 8 2 2}$ \\
Education & 300 & 0 & 3 & 0.94 & $\mathbf{0 . 8 6 4 2 5}$ \\
landholding size & 300 & 0.06 & 1.5 & 0.45 & $\mathbf{0 . 3 0 9 7 2}$ \\
$\begin{array}{l}\text { Tropical livestock unit(TLU) } \\
\text { Market distance in hour }\end{array}$ & 300 & 0 & 8.95 & 2.42 & $\mathbf{1 . 4 7 1 6 6}$ \\
$\begin{array}{l}\text { Source HHs income or HHs } \\
\text { engagement }\end{array}$ & 300 & 0.05 & 3 & 1.01 & $\mathbf{0 . 6 3 1 8 8}$ \\
Annual Income & & 1 & 3 & 1.64 & $\mathbf{0 . 8 3 0 6 3}$ \\
\hline
\end{tabular}

Source: Field survey data, 2020

Age: From the survey data the average house hold age was 42.8 years .This indicates that, surveyed household were at level of productive age. But, above 50 years old household heads were not diversifying their income. As their age increases their participation in income diversification reduces. On other hand, those HHs at the age level of $>15$ and $<50$ had a maximum tendency to participate in off/non-farm income diversification (from field data observation and key informants response of current study). So, age has an inverse relationship with income diversification of households ,i.e., when the age category of house hold is below or above a productive age there is a high dependency and low level of participation in income off - farm income generation activities.

Family size: From the survey result the average family size of households in the study were 6 . In many households the children were spent their time in school and come back to their home at night time or weekends, and their roll on income generation was very low rather than being dependent on family head. Due to this, a household heads were less participating on income diversification. Therefore, this has a negative relation with income diversification. Because, the family has a high of dependency burden and this reduces the annual income by increasing household expenditure or has a high propensity to consume the disposable HH income. On other hand, a household with a large family size with productive age category has a high probability for income maximization, by using these family members as a labor force. Berhanu et al. (2007) found that household human-capital endowments influenced the adoption of growth-oriented diversification patterns in southern Ethiopia. In eastern Zambia too, the sex, age and educational level of the household head together with the dependence ratio, seemed to have an effect on the proportions and levels of income from several of the sources.

Land holding size: From survey result, the average land holding size of the study area was 0.46 hectare and this indicates that a low land holding size and a high density of population. But, from the field survey data and key informant discussion information; a household with large size of land were less likely to participate in income diversification rather than specializing in only agricultural production to maximize the HH's annual income. Hence, land holding size has a negative relationship with non-farm income generation activities engagement, whereas; as a positive relationship with agricultural production. This is in line with the findings of Reardon et al. 
(2000), however, the FAO Riga study (Carletto et al. 2007) reported results that varied markedly between countries in this regard. The medium- and high-income trickles had more diversified income streams measured according to the number of sources per household and Simpson's. And also it agrees with Yishak (2015) in wolaita zone ,but not significantly. That is why; from the current study survey observation some households even with small plot of land would not shifted their livelihood strategy to non/off- farm or not participated on income diversification activities ; because of lack of skill training on off-farming .

Remittance/transfer: From the survey result only $20 \mathrm{HHs}(13.8 \%)$ receive remittance from their relatives/family members who live outside or inside the country. From those HHs who received the remittance money $60 \% \mathrm{HHs}$ were participated in income diversification. Cash income is positively affecting them to enter into non-farm income generation activities. There was a significant and positive relationship between the age of household head and the amount of transfer income and livestock income, and the same was applied to income share. The proportions and levels of transfer income could indicate two different things: first, households with an old head are vulnerable and as such are entitled to food aid, and secondly, the more mature households may have older children residing outside the home village and district, sending remittances to their parents (Kaisa Karttunen ,2009) from Zambia. Tropical livestock ownership (TLU): The average Livestock holding size (TLU) of the study area was 2.4217. From survey data maximum size is 8.95 and minimum is 0 . Therefore, a HH with large size of TLU less likely participate in income diversification beyond agriculture or livestock production .On other hand, a HHs with a few or no TLU were highly participated in non-farm/off farm income generation activities .

Annual income (cash asset): From survey result the average annual income amount was 12693.2483ETB and the maximum. is 42000.00 and minimum is $1170.00 \mathrm{ETB}$.This is observed from field survey data that a HH with good access of assets, and participated in more than two or more activities or diversify its livelihood strategy has a high annual return of income. There for, it reflects that the high connections of asset-activity - income or livelihood approach. Then it has a consistency with theory in the literature part. The livelihood approach developed by Ellis (2000a) defined a livelihood as consisting of "the assets (natural, physical, human, financial and social capital), the activities, and the access to these (mediated by institutions and social relations) that together determine the living gained by the individual or household". The livelihood approach emphasizes the role of the household's resources as determinants of activities and highlights the link among assets, activities and incomes.

Market distance: From survey result the average distance from market area was 1:00 hour and it negatively affects the participation of non/off-farming activities (income generation and diversification. A HH nearest to market center more likely engaged in income diversification activities, from survey observation these HHs were engaged in petty treading, local drink preparation, and food processing. But if the distance increases, the option could be agricultural production which is seasonal and no need of frequent travelling to market area.

Irrigation utilization: From survey result, there was only $6.9 \%(10) \mathrm{HHs}$ used irrigation for income maximization per year. From the data observation the household head implement irrigation, there were; their annual income was very large compared with not users. However, the absence of irrigation land /water source access (many of HHs were not users of irrigation, they were 135 among 145 surveyed HHs).However, it is positively affects the HHs' participation in income generation and diversification. The size of irrigable land as hypothesized is positively related with income diversification. Hence, households who have large irrigation land have better chance to diversify their income. The reason behind this is, that irrigation opportunities make produce crops two or three times per year instead of once which would create agricultural surplus for households who have irrigable land. This surplus can be used for doing nonfarm activities, particularly self-employment activities. The importance of irrigation water for agriculture was mentioned by Hussain (2007) who stated that irrigation water is a vital resource for many productive and livelihood activities. According to Samson et al. (2010), almost 95\% of households surveyed in East Harerghe Zone reported that their income had increased due to using irrigation in the dry season to produce existing crops two or three times per year instead of once. (Table 5).

Credit utilization/access/: From the survey result, 51\% HHs were accessed credit and the rest $49 \%$ HHs were not (because of collateral restriction or fear of risk or repayment date which is short and not appropriate and also interest rate issue).(Table 5) 
Table 5. Summary for independent categorical (dummy) variables

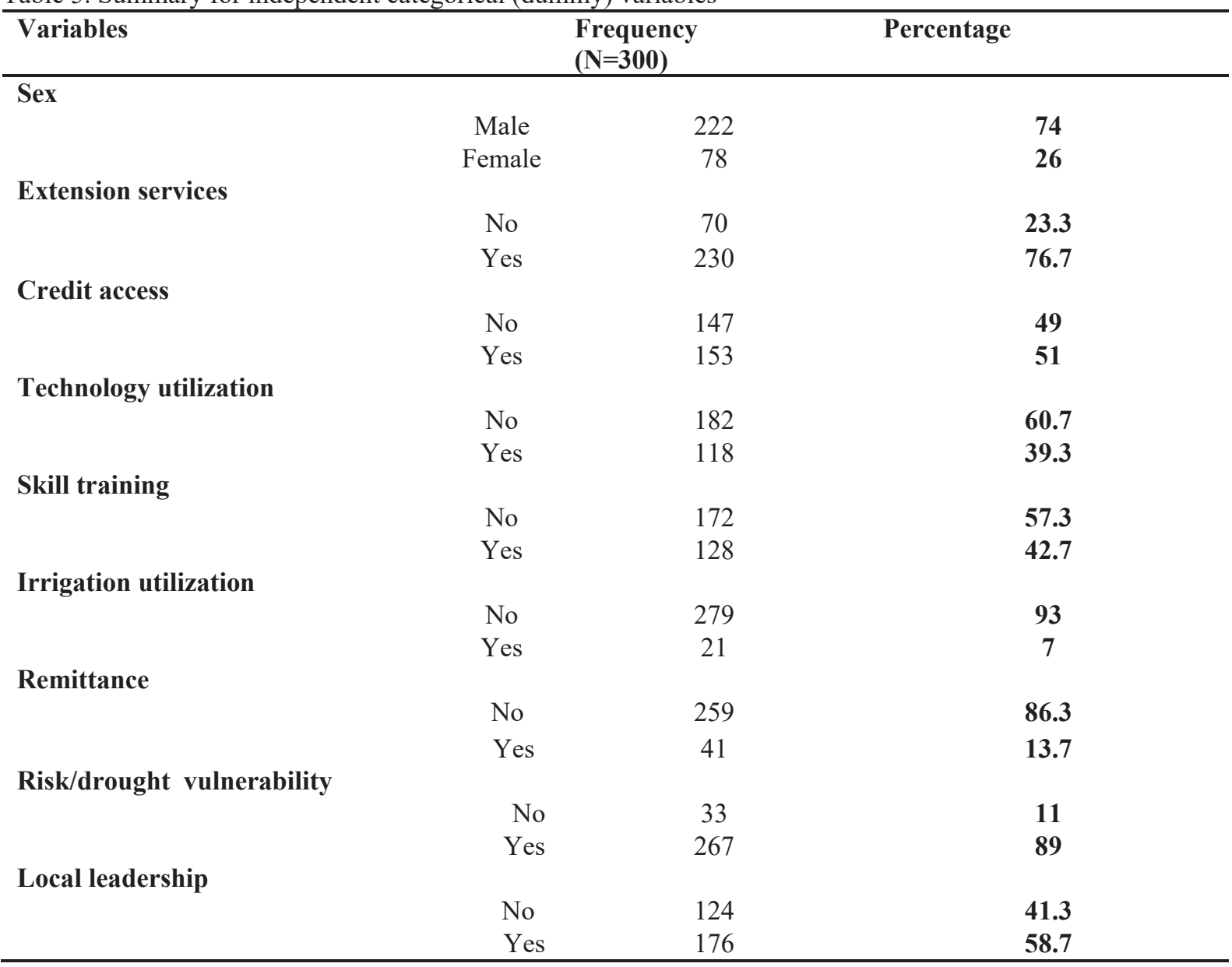

Source: Own computation from survey data, 202

\subsection{Econometric Analysis}

In this part the econometrics model defines the participation of farm households on income diversification activities. Thus before estimating the logistic regression model the following diagnostic tests should be considered whether the data set fulfills the measure assumptions of logit model. 
Table 6. Logistic regression model estimate for factors affecting rural household income diversification Logistic regression Number of obs $=300$ Wald chi2 $(16)=44.24$ Prob $>$ chi $2=0.0002$

Log pseudo likelihood $=\mathbf{- 4 5 . 2 6 0 9 6 1}$

Pseudo R2 $=0.6180$

\begin{tabular}{lllllll}
\hline Diversfctn & Odds Ratio & Robust Std. Err. & $\mathbf{Z}$ & $\mathbf{P}>\mathbf{z}$ & $\mathbf{9 5 \%}$ Conf. & Interval] \\
\hline Sex & 0.3725526 & 0.3067869 & -1.2 & 0.231 & & 1.871237 \\
Age & 0.9537533 & 0.0499268 & -0.9 & 0.366 & 0.860751 & 1.056804 \\
Mrktdist & 0.4773165 & 0.2102065 & -1.68 & $0.093 *$ & 0.201346 & 1.131538 \\
Famlsiz & 0.74379 & 0.1978397 & -1.11 & 0.266 & 0.441612 & 1.252738 \\
Landsiz & 0.7732494 & 0.6940411 & -0.29 & 0.774 & 0.133141 & 4.490841 \\
Tecno & 2.750729 & 1.722599 & 1.62 & 0.106 & 0.806115 & 9.386397 \\
Remit & 1.371674 & 0.7620957 & 0.57 & 0.569 & 0.461665 & 4.07544 \\
Exsvs & 1.399143 & 0.3003815 & 4.66 & $0.0221^{* *}$ & 0.640875 & 1.699719 \\
Creditacc & 1.270859 & .3002483 & 4.23 & $0.000 * * *$ & 0.20189 & 4.27584 \\
Education & & & & & & \\
1 & 1.322239 & 0.897187 & 1.47 & 0.141 & -0.43622 & 3.080693 \\
2 & 2.232162 & 1.002181 & 2.23 & $0.026 * *$ & 0.267924 & 4.1964 \\
3 & 1.1696 & 1.382381 & 0.85 & 0.398 & -1.53982 & 3.879017 \\
Localeader & 1.309778 & 0.8754795 & 0.4 & 0.686 & 0.353378 & 4.854632 \\
Irrig & 2.216054 & 2.469327 & 0.71 & 0.475 & 0.249514 & 19.68185 \\
Vulnerably & 6.191634 & 6.750733 & 1.67 & $0.094 *$ & 0.730703 & 52.46499 \\
TLU & 0.602606 & 0.1725568 & -1.77 & $0.077 *$ & 0.343788 & 1.056272 \\
Skilltra & 11.85967 & 8.642443 & 3.39 & $0.001 * * *$ & 2.843025 & 49.4726 \\
\hline
\end{tabular}

Source: Research model output, 2020

\subsubsection{The Factors affecting income diversification.}

The logistic regression model was applied to observe the effect of hypothesized explanatory variables on the probability of households' participation in income generation and diversification. Finally, among 15 explanatory variables ( 5 are continuous and 9 are discrete variables) included in the logit analysis, 7 variables were observed as a significant one. These variables are: education achievements of household (educ.), extension service(Exsvs), skill training(skilltra), market distance(marktdist),Tropical Livestock Unit(TLU) and vulnerability to drought/risk(vulnerably) and credit access to the households(creditacc).

Based on the result of logistic regression the following interpretation was given for each variable.

Education attainment: According to survey result, the variable educ(education), which is formal educational attainment by the household head, under second category has a positive and statistically significant effect on income diversification activities at 5\% level of significance. With an odds ratio of 2.232162 , household heads that completed secondary level of education are 2.232162 times more likely to participate on income diversification activities than illiterate household heads. Household heads with better educational attainment are more likely to participate in income diversification strategies due to their ability to acquire new knowledge and skills that may further enable them to be entrepreneur. Hence, it is hypothesized that education would affect income diversification positively (Dilruba and Roy, 2012 and Mideksa, 2015). Similarly, the study of Smith, (2007) on the determinants of household income in the Soviet Union found that human capital and demographic factors were the main determinants of household income. The study found that the well- educated, middle-aged and self -employed people had a relatively comfortable income. This finding is in line with the finding of various authors (Amare eta. al., (2013),Valdivia and Quiroz ,(1999), and Yishak,(2015).

Market Distance: The variable mrktdist(market distance), distance from nearby market, has a negative and statistically significant effect on the participation of rural farm household on income diversification activities at $10 \%$ level of significance. With an odds ratio of 0.4773165 , as market distance increased by a unit, it causes participation of that household on income diversification activities to decrease by 0.4773165 units. In other hand, an increment in distance from market causes that household not to participate on income diversification by 0.4773165 more amount, keeping other factors remain constant. This means, the negative relationship suggests that the likelihood of participating in diversified income activities declines as the distance from market center increases. Due to the distance of (which is very longer), the farmers will be discouraged from engaging income generation activities. This idea has a consistency with the idea of Yishak(2015), Tembo et al,2009.

Skill training on income generating activities: The variable skill training (skilltr) (Table 4) has a positive and strongly significant effect on income diversification activities at $1 \%$ level of significance. With an odds ratio of1 1.85967, heads that got skill training are 11.85967 times more likely to participate on income diversification 
activities than household heads that don't get skill training. This means households who took training was found to participate on nonfarm activities than the households who did not take the skill training since skill training was important factor for households to diversify their engagement in to nonfarm activities. Because it develops/builds up the knowledge and confidence of rural households to be engaged income diversification away from agriculture .This finding is in consistent with the results reported by Yishak(2016) at Wolaita zone and also consistent with study conducted by Dilruba and Roy (2012) that indicates the positive association of training and income diversification that nonfarm skill training significantly influenced income diversification strategies but inconsistent with finding of Mediksa (2015) at Oromiya (Bale Zone) which is negatively associated.

Tropical Livestock ownership (TLU): It is continuous variable. Livestock ownership is the amount of livestock owned by HHs. It is measured by Tropical Livestock Unit (TLU). The survey result revealed that the ownership of livestock has a negative and statistical significant effect on participation of non /off-farm income generation (diversification) activities at $10 \%$ level of significance. With an odds ratio of 0.602606 , as TLU increases by a unit, it decreases 0.602606 times a farming household's participation on non-/off farm income diversification. That means, if the farming house hold with a large number of a livestock unit therefore that household would not give an attention to other activities such as petty trading, off -farm (diversification) out of farming rather than specializing farm income which is very high .In other hand, households with a few number/no livestock ownership were more likely to participate in income diversification. It was shown in survey observation. So, this is similar with Yishak, (2015). that is the revealed negative association between livelihood diversification and number of TLU indicates that the herd size creates better opportunity to earn more income from livestock production .But, household with less number of livestock try to diversify their income portfolio by participating non/off-farm activities and this accelerate diversification. This idea supported by different studies Decorn and Kirshnan (1996) and Barrett et al., (2001).

Vulnerability to drought or risk: According the survey result the variable vulnerably (vulnerability to drought or risk) has a positive and statistically significant effect on farming household's participation on non-off/farm income generation activities (diversification) at 10\%. From this result we can see that a large probability of farming household to shift their farm income engagements like,crop production and livestock rearing when the occurrence of persistent drought or risks like animal death and crop damage by diseases. That why; from odds ratio result from table as we see 6.191634 , a unit increase in occurrence of drought/risk, ( i.e, vulnerability) in household livelihood ,then 6.191634 times increase farming household participation on diversification(non-farm income).the idea is the samr with the work of Barrett et al., 2001. According to Dercon (2002) rural households are pushed by either idiosyncratic shocks (individual specific shocks) such as illness or death of income generating household member, ill health of livestock or covariate or aggregate shocks such as drought in the community. Extension service of agent to farmers (Exsvs): According to the model output, extension service was found positive and has statistically significant influence on income diversification with the probability of at 5\% in the study area. This implies that extension service is one of the vital factors that affect credit access in the study area. This implies that, an improvement of extension services in the study area will lead to a positive contribution towards income diversification (on farm and off-farm) in the study area. This research output is consistent with the finding of Beck T (2007), Dzadze P,et al.,(2012) who noted that extension services play a crucial role in empowering farmers with farming techniques, knowledge and management skills(Kiplimo et al,2015, Dzadze et al.2012).

Credit Access (creditacc): As expected, Credit access variable was found positive and has statistically significant influence on credit access with the probability $(\mathrm{p}=0.000)$ at $1 \%$ in the study area. This indicates that the smallholder households applying Credit access to run rural income generating activities such as on-farm and offfarm activities. The finding is consistent with several research findings including Babatunde, 2010, Beneberu A., 2019) show that the significant determinants of income on livelihood.

\section{CONCLUSION AND RECOMMENDATION}

\subsection{Conclusion}

The issue of the poverty reduction and economic development takes a high position in every corner of the current World. However, there are many problems exist and significantly affect the rural area by varying with time and space. This paper analyzes the factors that affect income diversification of rural households in Sodo Zuria district ,Wolaita zone, Ethiopia. Based the econometric computation, 15 hypothesized explanatory variables; 7 variables were significantly affect the participation of rural households on income diversification in the study area. These are education, skill training of income generation\& diversification, distance to the market, ownership of livestock, Vulnerability to risk and drought, extension services and credit accesses. The findings of the study indicate that $62 \%$ rural households in the study area were determined by income diversification of different agricultural and non-agricultural activities. The rest ones were insignificant and need farther inquiry.

\subsection{Recommendation}

Based on the study findings the possible recommendations were: Government and non-governmental organizations 
and any other concerned stakeholders on rural development; should enable the conducive environment and provide skill training on the area of on-farm and off-farm income diversification, credit access, education access to rural households should increase, households should follow modernized system of livestock management, extension service providers should reach to rural households, create resilient economy for shocks are the main forwards of this study.

\section{References}

1. AmdissaTeshome1, March 2006.Agriculture, Growth and Poverty Reduction in Ethiopia: Policy Processes Around the New PRSP (PASDEP).Future agriculture.

2. Asmah, E. E. 2011. Rural Livelihood Diversification and Agricultural Household Welfare in Ghana. Journal of Development and Agricultural Economics, 3(7): 325-334.

3. Awuor Z. 2007. Agricultural Growth, Rural Poverty and Hunger in Africa. African Association of Agricultural Economists (AAAE) Conference Proceedings, pp465-468, August 20-22, 2007, Accra, Ghana.

4. Babatunde, R. O., Olagunju, F. I., Fakayode, S. B. and Adejobi, A. O. 2010.Determinants of participation in off-farm employment among small-holder farming households inKwara State, Nigeria.

5. Barrett, C. B., Reardon, T. and Webb, P. 2001. Non-farm income diversification and household livelihood strategies in Rural Africa: Concepts, dynamics, and policy implications",Food Policy, 26 (4): 315

6. Bob Rijkers. 2008. Rural non-farm enterprises in Ethiopia:challenges and prospects understanding the constraints to continued rapid growth in Ethiopia: The role of agriculture Africa Regions, World Bank, November 2008.

7. CIDA. 2013. Assessment of CIDA's food security strategy and funding in Ethiopia. Canadian Food Security Policy Group. Authored by Reach Consult Ltd. and Canadian Hunger Foundation, March 2013.

8. CSA.April30/2017.www.worldmeters.info/...population/.....April 30/2017

9. Djurfeldt, G., R. Larsson, B. Holmquist, M. Jirström and A. Andersson. 2008, 2013 . African Farm Dynamics and the Sub-Continental Food Crisis: The Case of Maize. Acta Agriculturae Scandinavica, Section C- Food Economics, 5(2): 75-91.

10. EEA. 2016. Report on the Ethiopian economy. Volume VI2016/17. Addis Ababa. Ethiopian Economic Association.

11. Ellis, F. (1999). Rural livelihood diversity in developing countries: evidence and policy implications. Overseas Development Institute (ODI), Natural Resource Perspectives, Number 40.

12. Ellis, F. (2005). Small-Farms, Livelihood Diversification andRural-Urban Transitions: Strategic Issues in Sub-Saharan Africa. A Paper prepared for the Research Workshop on: "The Future of Small Farms." Withersdane Conference Centre, Wye,Kent, UK, 26-29 June 2005

13. Ellis, F. and Freeman, H.A. 2004.Rural livelihoods and poverty reduction strategies in four African countries. Journalof Development Studies 40(4): 1-30.

14. FDRE. 2010. Ethiopia's agricultural sector policy an investment framework 2010-2020. Federal Democratic Republic of Ethiopia, Ministry of Agriculture and Rural Development. Draft final report, 15 September 2010.

15. Goodrich, R. 2001. Sustainable rural livelihoods: A summary of research in Mali and Ethiopia.

16. Greene, W. 2000. Econometric analysis. Englewood Cliffs, NJ: Prentice Hall

17. Haggblade, S., Hazell, P.B.R. and Reardon, T. 2007.Transforming the Rural Non-farm Economy, John Hopkins University Press, Baltimore, USA.

18. Haggblade, S., P. Hazell and T. Reardon. (2010). The Rural Non-farm Economy: Prospects for Growth and Poverty Reduction. World Development, 38(10):1429-1441

19. IFAD (International Fund for Agricultural Development). 2011. Rural Poverty Report. New Realities, New Challenges, New Opportunities for Tomorrow's Generation, Rome, Italy.

20. IMTFI Working Paper 2012-3,Managing Risks: How do Poor Households Smooth Their Income and Consumption? (An Examination of Poor Households in Yogyakarta, Indonesia) CaturSugiyanto, Faculty of Economics and Business UGM Sri Yani Kusumastuti, Graduate Student, UGM

21. KaisaKarttunen,(2009). Rural income generation and diversification A Case Study in Eastern Zambia, University of Helsinki. Department of Economics and Management

22. Losch, B., S. Freguingresh and E. White. (2011). Rural Transformation and Late Developing Countries in a Globalizing World: A Comparative Analysis of Rural Change. Final Report of the Rural Struc Program, Revised Version. Washington, DC: World Bank.

23. MEDaC (Ministry of Economic Development and Planning),2008. Survey of the Ethiopian Economy. Review of post reform development. MEDAc, Addis Ababa.

24. Mideksa Fufa ,June 2015; "Factors Responsible for Income Diversification among Rural Farm Households in Agarfa District, Bale Zone, Oromia National Regional State, Ethiopia."

25. MoFED (Ministry of Finance and Economic Development).2002. Ethiopia: Sustainable development and poverty reduction program. pp. 34, 71 \& 76.Federal Democratic Republic of Ethiopia (FDRE) Ministry of 
Finance and Economic Development (MoFED), Addis Ababa, Ethiopia.

26. Mwanza Joseph F., 2010-2011. "Assessment of Factors of household capital/assets that influence income of smallholder farmers under International Development Enterprises (IDE) in Zambia” . Promoter: Dr. ir.StijnSpeelman

27. Nghiem, L. (2010) Activity and Income Diversification: Trends, Determinants and Effects on Poverty Reduction. the Case of the Mekong River. International Institute of Social Studies of Erasmus University (ISS).

28. Nagler, P and Naudé, W. 2014. Non-farm Entrepreneurship in Rural Africa: Patterns and Determinants. Discussion Paper No. 8008. Forschungsinstitut zur Zukunft der Arbeit (IZA) (Institute for the Study of Labour), Bonn, Germany.

29. Policy Helsinki 2009.Rural Income Generation and Diversification - A Case Study in Eastern Zambia .

30. Reardon, T. (1997).Using Evidence of Household Income Diversification to Inform Study of the Rural Nonfarm Labor Market in Africa. World Development, 25(5):735-747

31. Rural Poverty Report 2011, the International Fund for Agricultural Development (IFAD)

32. Samson Eshetu, Belayneh Belete, Degeye Goshu, Belay Kassa, Demeksa Tamiru, Estifanos Worku, Zelalem Lema, Addisu Delelegn, Josephine Tucker and Zemede Abebe. 2010. Income Diversification Through Improved Irrigation in Ethiopia: Impacts, Constraints and Prospects for Poverty Reduction, Research-inspired Policy and Practice Learning in Ethiopia and the Nile Region, Evidence from East Harerghe Zone, Working Paper 14, Oromiya Region, Ethiopia.

33. Stifel, D. 2010. The rural non-farm economy, livelihood strategies and household welfare. African Journal of Agricultural and Resource Economics,4(1).

34. Todaro, M. P. and Smith, S. C. 2009. Economic Development, 10th Edition. Pearson Education Limited, Harlow, England.

35. UN, 2012. United Nations conference on Sustainable Development,2012)

36. UNDP (United Nations Development Programme). 2016. Country Economic Brief, Ethiopia. [On line] Available from: http://www.et.undp.org. [Accessed on 1 February 2016].

37. Winters, P., T. Essam, A. Zezza, B. Davis and C. Carletto(2010). Patterns of Rural development: A CrossCountry Comparison Using Microeconomic Data. Journal of Agricultural Economics, 61(3):628-651

38. World Bank. 2008. World Development Report 2008: Agriculture for Development. World Bank, Washington DC.

39. World Bank.2009.Diversifying the rural economy: An assessment of the investment climate for small and informal enterprises in Ethiopia," October 6, 2009.

40. Yishak Gecho, Gezahegn Ayele, Tesfaye Lemma, Dawit Alemu. Rural Household Livelihood Strategies: Options and Determinants in the Case of Wolaita Zone, Southern Ethiopia. Social Sciences. Vol. 3, No. 3, 2014

41. Kothari, C. 1990. Research Methodology: Methods and Techniques, 2nd Edition. Wishwa, Parakashan, New Delhi.

\section{Acknowledgement}

The present researchers kindly acknowledges all this study participants in Sodo Zuria District Agricultural office employees for their active participation and good will in providing all necessary information based on authors request. 